63 巻 612 号(1997-8)

$$
\begin{aligned}
& \text { セラミックスベアリングインナーレース面の総形鏡面研削* } \\
& \begin{array}{r}
\text { 周 立 波*1, 立花 烹*2, 庄 司 克 雄*3, 厨川常 元*3 } \\
\text { 芳 賀 } \text { 務 }^{* 4} \text {, 海 野邦彦*5, 大 下 秀 男*6 }
\end{array}
\end{aligned}
$$

\title{
Form Mirror Grinding of Inner Race of Ceramic Bearing
}

\author{
Libo ZHOU, Toru TACHIBANA, Katsuo SYOJI, Tsunemoto KURIYAGAWA, \\ Tsutomu HAGA, Kunihiko UNNO and Hideo OHSHITA
}

\begin{abstract}
In this paper, we consider the cross-sectional profile accuracy of both a trued wheel and a ground workpiece. The Arc Truer is a truing/dressing device designed for a superabrasive grinding wheel with a convex profile. The truer has the advantages of obviating dressing after truing, and of producing sharp cutting edges that protrude from the wheel surface. Some kinematic errors, called alignment errors, of the Arc Truer have been analyzed, and the influence of the errors on the wheel profile has been clarified. An ultraprecision cylindrical grinding machine equipped with a hydrostatic wheel spindle and a fine infeed mechanism driven by piezoelectric actuators has been specially developed for mirror grinding using extremely fine grit wheels. Finally, a mirror surface on a $\mathrm{Si}_{3} \mathrm{~N}_{4}$ ring with a roughness of less than $50 \mathrm{~nm} R_{\max }$ and a profile error of less than $\pm 1 \mu \mathrm{m}$ was obtained using a \#5000 mesh-size diamond wheel.
\end{abstract}

Key Words: Grinding, Cylindrical Grinding, Dressing, Generating Motion, Arc Truer, Truing, Diamond Wheel, Form Mirror Grinding, Inner Race of Ceramic Bearing

\section{1. 緒言}

レジノイドボンドやメタルボンドのようなマトリッ クス型超砥粒ホイールでは, ツルーイングを行った後 にドレッシングが必要である．したがってドレッシン グによって形状精度が劣化するため, 総形研削のよう に形状精度が問題になる場合には，超砥粓ホイールの 実用化がなかなか進まないのが現状である ${ }^{(1) \sim(3)}$.

筆者らは, カップ型の通常砥石を用いてツルーイング を行えばドレッシングが不要であり，しかも高い真直 度が得られることに着目した. そして直線包絡による 円弧断面ツルーイング装置（以下,アークツルアと呼 ぶ）を開発した ${ }^{(4)}$.一方，粒径がミクロンオーダのレジ ノイドボンド極微粒ダイヤモンドを用いた研削では, 砥粒に大きな研削力が作用すると研削点に発生した研 削熱で結合剤が軟化し，砥粓が埋没して良好な研削が 維持できない( ${ }^{(5)}$.このような砥粒の埋没を防ぐには振動 が小さく, 微小切り込みの可能な研削盤が不可欠であ るという考えから，積層型圧電アクチュエータを応用 した微小切り込み装置を備えた超精密円筒研削盤を試 作した.その結果, \#5000のレジノイドボンドダイヤモ

* 原稿受付 1996 年 6 月 11 日.

*1 正員, 東北大学工学部 (画 980-77 仙台市青葉区荒巻字青葉) (現: Gintic Institute of Manufacturing Technology, Singapore)

*2 正員, 東北大学大学院, ミクロン精密(株) (画 990-23 山形市 蔵王上野 578-2).

*3 正員, 東北大学工学部.

*4 日立精機 (株) (恶 270-11 我孫子市我孫子 1).

*5 正員, 豊田工機(株)（画448 刈谷市朝日町 1-1).

*6 大阪ダイヤモンド工業(株) (-593 堺市鳳北町 2-80).
ンドホイールを用いてジルコニアセラミックスの鏡面 研削に成功した ${ }^{(6)}$.

本研究ではこれら二つの技術を結合し, 高精度の円弧 断面を総形鏡面研削することを試みる．最初にアーク ツルアの精度向上について検討し, その後, 窒化珪素 セラミックス製のボールベアリングインナーレース面 の鏡面研削を試みる.

\section{2. ッルーイング装置}

$2 \cdot 1$ ホイールの断面曲線＼cjkstart前報(4)ではアークツ ルアを試作し, 直線包絡により CBN ホイールを円弧断 面にツルーイングできることを示した．しかし試行錯 誤法によって最終的に得られた半径誤差は土0.1 $\mathrm{mm}$, 形

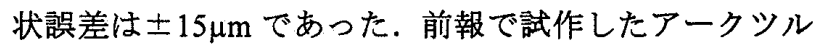
アでは, ツルア主要部を片持ちで懸架し旋回させる構 造を採用していた。 そのため，ツルーイング抵抗の垂 直成分によってツルア（カップ砥石）上下往復運動軸 が傾き, 大きな半径誤差や形状誤差を生じさせる原因 となった．またその後の検討により，研削盤テーブル 面に対するツルア旋回軸の直角度がツルーイング後の ホイールの形状精度を左右することも明らかになった。 ここでまず, 装置精度に起因するツルアの運動誤差 (以 下，アライメント誤差と呼ぶ）がツルーイング精度に 与える影響について考察し，その改善を行った。

図 1 (a)は，ツルア（カップ砥石）正面がツルーイン グ時に描く創成面とホイールとの干涉の様子を示した ものである、いま図のように，ホイール中心に原点 $\mathrm{O}$ 


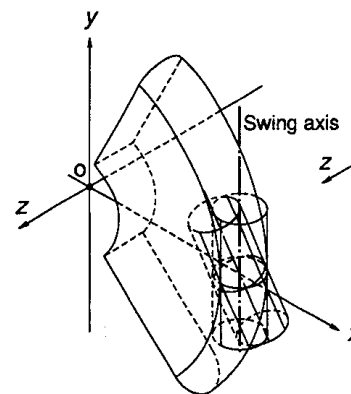

(a)

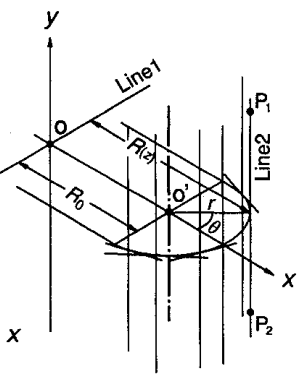

(b)

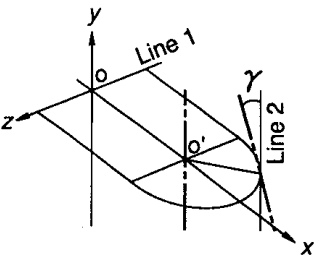

(c) Inclination of $\gamma$

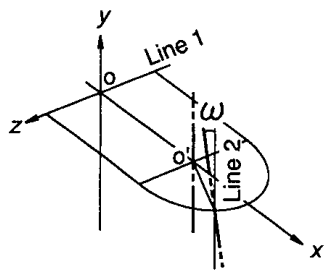

(d) Inclination of $\omega$

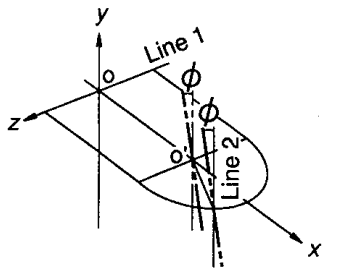

(e) Inclination of $\phi$

Fig.1 Arc profile by envelope of straight lines

を置き, ホイール回転軸を $z$ 軸, 水平軸を $x$ 軸とする $(x$, $y, z)$ 座標系を設定する.図 1 (b)は，ホイールの断面 形状を半径 $R(z)$ で表わし, ツルアによる創成運動の軌跡 (Line 2) との関係を示したものである. 図に示したよ うに, ツルアによる創成運動の軌跡通りにホイールが 成形されると仮定すれば, ホイール半径 $R(z)$ は二つの直 線 Line 1 ( $z$ 軸) と Line 2 との距離, 寸なわち共垂線の 長さになる. ここで, Line 2 を任意の 2 点 $\mathrm{P}_{1}\left(x_{1}, y_{1}, z_{1}\right)$, $\mathrm{P}_{2}\left(x_{2}, y_{2}, z_{2}\right)$ を通る直線

$$
\frac{x-x_{1}}{x_{2}-x_{1}}=\frac{y-y_{1}}{y_{2}-y_{1}}=\frac{z-z_{1}}{z_{2}-z_{1}}
$$

で表わせば, $z$ 軸（Line 1）と Line 2 の共垂線の長さ $R(z)$ と $z$ 座標は次式で与えられる。

$$
\begin{aligned}
& R(z)=\frac{\left|\left(x_{2}-x_{1}\right) y_{1}-\left(y_{2}-y_{1}\right) x_{1}\right|}{\sqrt{\left(x_{2}-x_{1}\right)^{2}+\left(y_{2}-y_{1}\right)^{2}}} \\
& z=z_{1}-\frac{\left(z_{2}-z_{1}\right)\left\{\left(x_{2}-x_{1}\right) x_{1}+\left(y_{2}-y_{1}\right) y_{1}\right\}}{\left(x_{2}-x_{1}\right)^{2}+\left(y_{2}-y_{1}\right)^{2}}
\end{aligned}
$$

(2)式と(3)式はツルーイングによって創成されるホイー ル断面形状を与える.

\section{$2 \cdot 2$ アークッルアのアライメント誤差の影響}

ツルアとホイールの接触点の軌跡は, アークツルアが 正しく設置されアライメント誤差が無いとすれば,

$$
\left[\begin{array}{l}
x \\
y \\
z
\end{array}\right]=\left[\begin{array}{c}
R_{0}+r \cos \theta \\
f \\
r \sin \theta
\end{array}\right]
$$

で与えられる点 $(x, y, z)$ を通る直線群 (Line 2) となる. ここで $R_{0}$ は旋回中心 $\mathrm{O}^{\prime}$ からホイール軸（ $z$ 軸）までの 距離, $r$ はツルアの旋回半径, $\theta$ は旋回軸周りの旋回角 である.また, 任意の值 $f$ に相異なる二つの值を与えれ ば，これら 2 点を通る直線 (Line 2) の方程式(1)が決定 される.

次に, ツルーイング装置のアライメント誤差につい て考える。 以下に示すように三つのアライメント誤差 を想定し，ツルーイングされるホイール断面形状への 影響を検討する．まず図 1 ( c ) のように, ツルアの上下 往復運動軸だけが旋回軸（ $y$ 軸に平行）に対して角度 $y$
だけ傾き，円錐母面を形成する場合を考える．これは， 前報 ${ }^{(4)}$ で試作したように旋回軸が片持ち構造で, ツルア とホイールの接触圧によって上下往復運動軸が角度 $\gamma$ だけ傾く場合に相当する．また，本来平行であるべき アークッルアの旋回軸と上下往復運動軸が製作誤差に より $\gamma$ の交差角を持つ場合と考えることもできる。こ のときの創成運動の軌跡 (Line 2 の直線群) に対する $\gamma$ の影響は次式の変換行列 $A$ で表わすことができる.

$$
A=\left[\begin{array}{cccc}
1 & 0 & 0 & f \cos \theta \sin \gamma \\
0 & \cos \gamma & 0 & 0 \\
0 & 0 & 1 & f \sin \theta \sin \gamma \\
0 & 0 & 0 & 1
\end{array}\right]
$$

次に図 $1(\mathrm{~d})$ のように，正しく設置された旋回軸に対 して往復運動軸が角度 $\omega$ だけ傾きねじれの位置にある 場合を考える.この場合, 創成運動の軌跡 (Line 2 の直 線群）は，図 1 (a)に示すように一葉双曲面を形成する. このとき $\omega$ の影響は変換行列 $B$ で表わすことができる.

$$
B=\left[\begin{array}{cccc}
1 & 0 & 0 & -f \sin \theta \sin \omega \\
0 & \cos \omega & 0 & 0 \\
0 & 0 & 1 & f \cos \theta \sin \omega \\
0 & 0 & 0 & 1
\end{array}\right]
$$

最後に図 $1(\mathrm{e})$ のうう, 往復運動軸と旋回軸が共に $\omega$ だけ傾いた場合を考える（この場合の $\omega$ を $\phi$ とおく）. このとき $\phi$ の影響は変換行列 $C$ で表わすことができる.

$$
C=\left[\begin{array}{cccc}
1 & 0 & 0 & 0 \\
0 & \cos \phi & -\sin \phi & 0 \\
0 & \sin \phi & \cos \phi & 0 \\
0 & 0 & 0 & 1
\end{array}\right]
$$

さらに往復運動軸と共に旋回軸も $z$ 軸周りに傾いた 場合も考えられるが，これはホイール円周上のツルー イング位置が変わるだけで, ツルーイングにおける本 質的な形状誤差とはならない.

2 -3 ホイール断面形状の誤差 上述した運動誤 差は互いに独立であるから，これらのすべてが存在し た場合, Line 2 が通る各点の座標 $(x, y, z)$ は次式で与え られる。

$$
\left[\begin{array}{l}
x \\
y \\
z \\
1
\end{array}\right]=C \cdot B \cdot A\left[\begin{array}{c}
R_{0}+r \cos \theta \\
f \\
r \sin \theta \\
1
\end{array}\right]
$$


(8)式の $f$ に相異なる二つの值を代入して得られる 2 点の座標を，(2)，(3)式に代入すれば, ホイールの断面 形状が求められる.

これらの結果を基にして, 所与の旋回半径 $r$ からの 偏差をツルーイングによるホイール断面の形状誤差と 定義して， $\gamma ， \omega ， \phi$ のアライメント誤差による影響 について調べた，図2に $\gamma$, 図3に $\omega$, 図 4 に $\phi$ をそ れぞれ単独に変化させたときのホイール断面形状誤差 を示す。

まず図 1 ( c )のように, ツルアの上下往復運動軸が傾 き $y$ を持った場合,あるいは旋回軸は正しく $y$ 軸に平行 に設置されながら，アークツルアの製作誤差により上 下往復運動軸が $y$ 軸に対して傾きを持つ場合, ツルーイ ング後のホイール断面の形状誤差は左右対称の $\mathrm{W}$ 型に なる（図 2). そして傾き角 $y$ が大きくなるほど, 形状 誤差は大きくなり, またホイール断面の近似半径は所 与の半径より小さくなる.

前報 ${ }^{(4)}$ で試作したアークツルアは, カップツルア全体 を吊り下げる設計にしたため支持剛性が十分でなく， ツルアとホイールの接触圧で上下往復運動軸が傾いて しまった. 前報の実験で $\mathrm{W}$ 型の形状誤差が生じたのは, これが原因と考えられる.

また図 1 (d)のように, ツルア上下往復運動軸が正し く設置された旋回軸とねじれ角を有するアライメント 誤差 $\omega$ の場合は $\mathrm{M}$ 型の形状誤差になり, 近似半径は所 与の半径よりも大きくなる（図 3). しかしその影響は, $\gamma$ の約 1/3である.さらに図 1 (e)のように, 旋回軸がア ライメント誤差 $\phi$ を有する場合の影響は V 型になり, その近似半径が所期の旋回半径より大きくなる傾向が あるが，その影響は $y$ のおよそ $1 / 20 〜 1 / 15$ 程度である (図 4).

2.4 アークッルアの改良前報の研究(4) では, ツルーイング原理の検証が主目的であったため, ツル ーイング精度について十分な検討はなされなかった. しかし本研究での検討の結果, 各種のアライメント誤 差がツルーイング後のホイールの形状誤差に大きく影 響することがわかった。 そこでこれらの検討結果に基 づき，新たにアークツルアを試作した．図 5 に，今回 試作したアークツルアの構成を示す. 基本的には, 前 報のプロトタイプのものと同様, 以下の四つの運動機 構を持つ. カップツルア（通常砥石）の回転(1)はスピ ードコントロールモータで与え, 上下往復運動(2)はク ランク機構を用い, ステッピングモータで駆動した。 旋回運動(3は, 旋回用のステッピングモータとタイミ ングベルトを組み合わせて，ステッピングモータの出 カパルス数をカウントすることにより与えた．旋回範 囲は，オープンループで最小 $0.1^{\circ}$ ステップの制御が可 能である. 切込み動作(4)は, 直動ベアリングをガイド にして，ステッピングモータとボールネジの組み合わ せで最小 $1 \mu \mathrm{m}$ の切込みが可能である. ツルーイングの 際には, カップツルアの上下往復運動に同期させて所

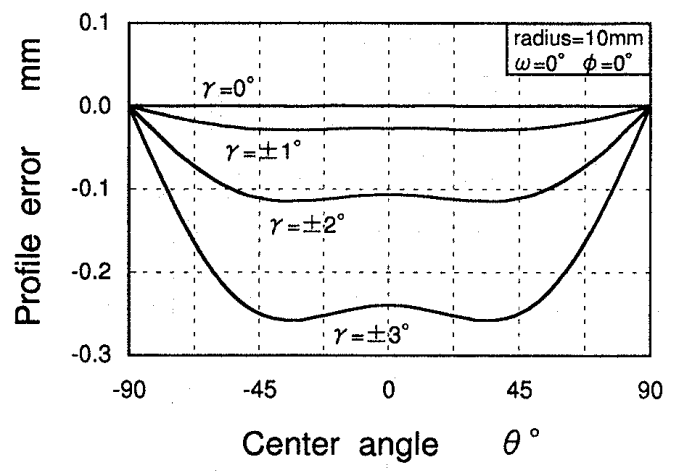

Fig.2 Influence of inclination $\gamma$ of reciprocation axis

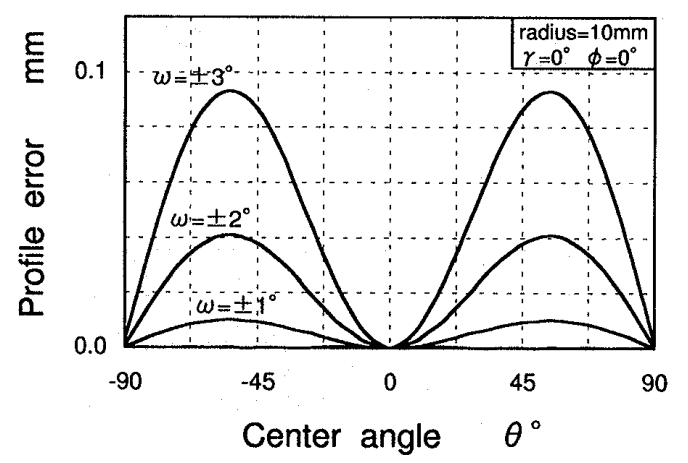

Fig.3 Influence of inclination $\omega$ of reciprocation axis

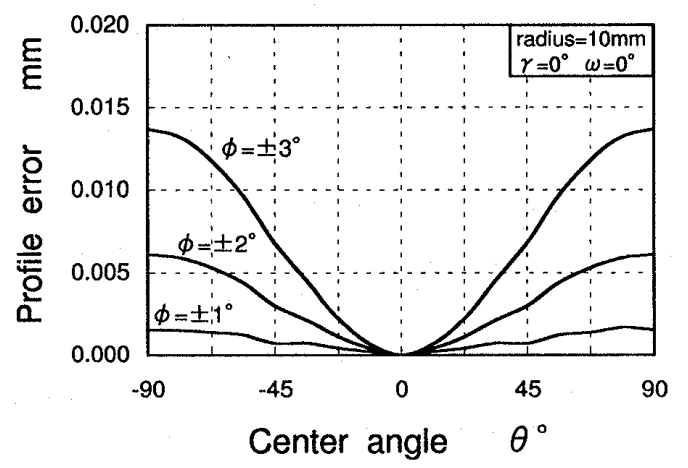

Fig.4 Influence of inclination $\phi$ of swing center axis and reciprocation axis

定の切込みと旋回送りを与える仕組みになっている. 切込み動作については, プログラムの変更だけで, 旋 回送り角 $\alpha$ に対して同期，非同期の切り替えができる ようにした。これは, 両端のタリー（旋回反転部での 一時停止）における過剩切込みがツルーイング精度の 劣化の原因となるという前報の研究結果に基づき, 切 込みの動作籍囲を旋回籍囲と無関係に設定できるよう にエ夫したものである.

また工作物の目標加工精度は $\pm 1 \mu \mathrm{m}$ であることから アークツルアの試作にあたり次の点を改善した。まず 旋回軸を両端支持にすることにより支持剛性の向上を 図った結果，判性はツルア回転軸方向で $1 \mathrm{~N} / \mu \mathrm{m}$ から $10 \mathrm{~N} / \mu \mathrm{m}$ に向上した.さらにツルーイングにおけるホイ 


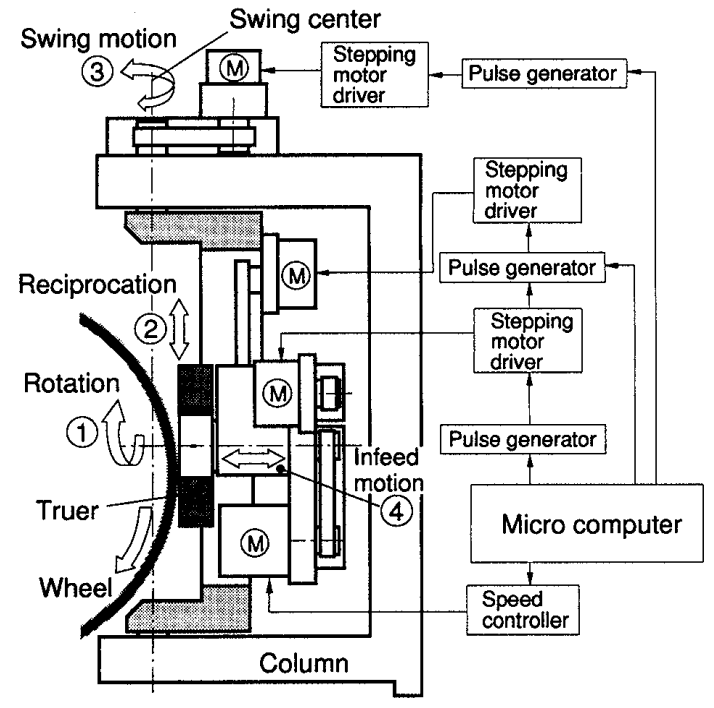

Fig.5 Schematic drawing of the Arc Truer

Table 1 Specifications of the Arc Truer

\begin{tabular}{|c|c|c|}
\hline (1) & $\begin{array}{l}\text { Drive } \\
\text { Truer size } \\
\text { Speed }\end{array}$ & $\begin{array}{l}\text { AC speed-control motor } \\
90 \mathrm{~mm}^{2} \times 50 \mathrm{~mm}^{H} \times 20 \mathrm{~mm}^{\top} \\
45 \sim 700 \mathrm{rmm}\end{array}$ \\
\hline (2) & $\begin{array}{l}\text { Drive } \\
\text { Stroke length } \\
\text { Speed }\end{array}$ & $\begin{array}{l}\text { Stepping motor+Crankshaft } \\
40 \mathrm{~mm} \\
3.8 \sim 9.0 \mathrm{~m} / \mathrm{min}\end{array}$ \\
\hline (3) & $\begin{array}{l}\text { Drive } \\
\text { Swing range } \\
\text { Resolution } \\
\text { Lost motion }\end{array}$ & $\begin{array}{l}\text { Stepping motor } \\
180( \pm 90) \text { deg } \\
0.1 \text { deg/pulse } \\
\sim 0.5 \text { deg }\end{array}$ \\
\hline (4) & $\begin{array}{l}\text { Drive } \\
\text { Stroke length } \\
\text { Swing radius } \\
\text { Infeed resolution }\end{array}$ & $\begin{array}{l}\text { Stepping motor+Ball screw } \\
40 \mathrm{~mm} \\
0 \sim 25 \mathrm{~mm} \\
1 \mu \mathrm{m} / \mathrm{step}\end{array}$ \\
\hline
\end{tabular}

ール断面形状誤差が加工形状に転写されることからそ の許容範囲を $\pm 0.5 \mu \mathrm{m}$ 以下とした．そこでアークッルア の製作誤差および研削盤への取り付け誤差は前節で解 析したアライメント誤差 $\gamma ， \omega ， \phi$ で表わされること から，それぞれ次の許容值に設定した，最も誤差の影 響の大きい $\gamma$ を考慮してツルアの上下往復運動軸と旋 回軸との平行度（すなわち $\gamma$ および $\omega$ ）は可動範囲 $40 \mathrm{~mm}$ 内で $0.17^{\prime}$ 以内, また研削盤テーブル面に対する 旋回軸の直角度誤差（すなわち $\phi$ ） は $0.43^{\prime}$ 以下にした.

表 1 にアークッルアの仕様, 図 6 に円筒研削盤上で使 用中の写真を示す.

\section{3. ツルーイング精度}

図 7 は,アークツルアにより $1.0 \mu \mathrm{m} / \mathrm{stroke}$ の定切込み を与えてツルーイングしたホイール断面形状の一例で ある。旋回軸を両端支持構造として剛性を向上させ， 製作誤差および研削盤への取り付け誤差を起因とする アライメント誤差を許容值以下にした結果, 形状誤差

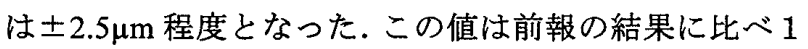
桁以上小さくなった. しかし目標の精度に到達してお らず,さらに誤差要因について詳細に検討したところ 形状誤差は比較的周波数の高い成分と周波数が低いう ねり成分からなることが分かった。これらをそれぞれ

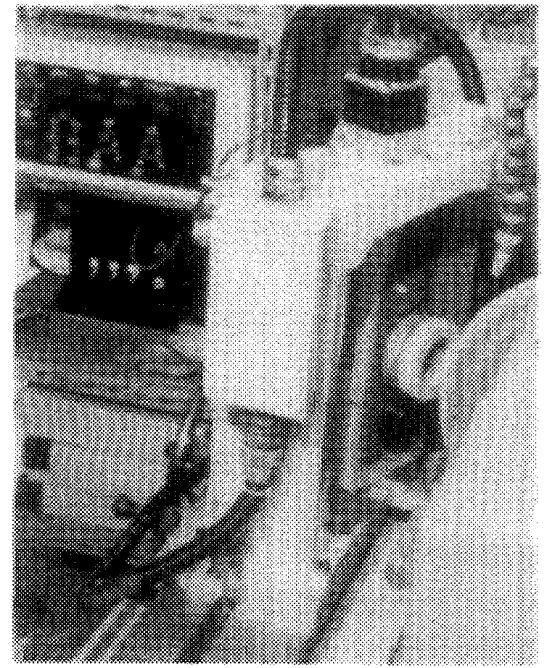

Fig.6 Photograph of the newly developed Arc Truer

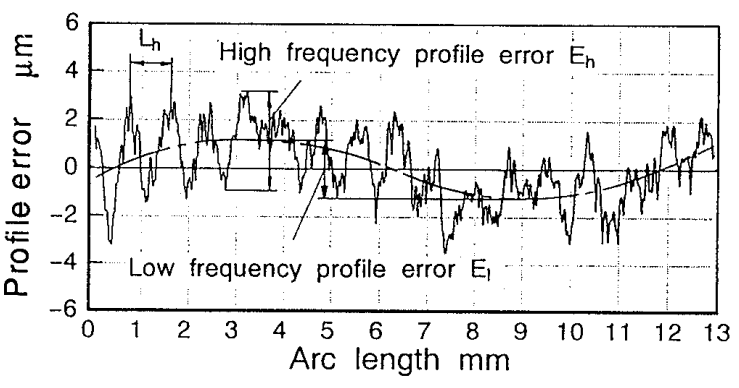

Fig.7 Wheel profile trued by the new Arc Truer

高周波誤差と低周波誤差と定義して原因を考察した。

図 8 は, 旋回送り角 $\alpha$ を変えたときのホイール断面形 状の変化である．この結果によれば， $\alpha$ がさくなる に伴って高周波誤差が減少し, 代わりに低周波誤差が 大きくなった. いまツルアの旋回送り角 $\alpha$ は上下往復 運動の反転時に与えているから, ツルーイング後のホ イール断面形状は旋回送り角 $\alpha$ に対応した正多角形に なる。これが高周波誤差である.したがって旋回送り 角 $\alpha$ を小さくすれば高周波誤差の振幅は減少し，滑ら かな円弧が得られる。こころが，旋回送り角 $\alpha$ が小さ くなると,旋回 1 回当たりの総切込み回数 $n$ が増加する. アークッルアの円弧創成は, ツルアに低結合度の通常 砥石を用いることにより，往復運動の反転時に与えら れるツルアの切込み量 $\Delta$ からツルアの摩耗量 $\delta$ を差し 引いた残留切込量 $(\Delta-\delta)$ が十分小さいことが前提とな っている(4). しかし 1 ストロークの残留切込量 $(\Delta-\delta)$ が十分小さくてもnが増加すれば 1 旋回あたりの累積 残留切込量 $\Sigma(\Delta-\delta)$ が増大し, 旋回開始時と終了時で旋 回半径が変わり低周波誤差の原因となる.

このように大きな振幅の高周波誤差が発生するのは 旋回送り角が大きいのが原因であるが，旋回送り角を 単に小さくしただけでは低周波誤差が増大する.

そこで旋回送り角を小さくせずに, 旋回行程毎に位相 


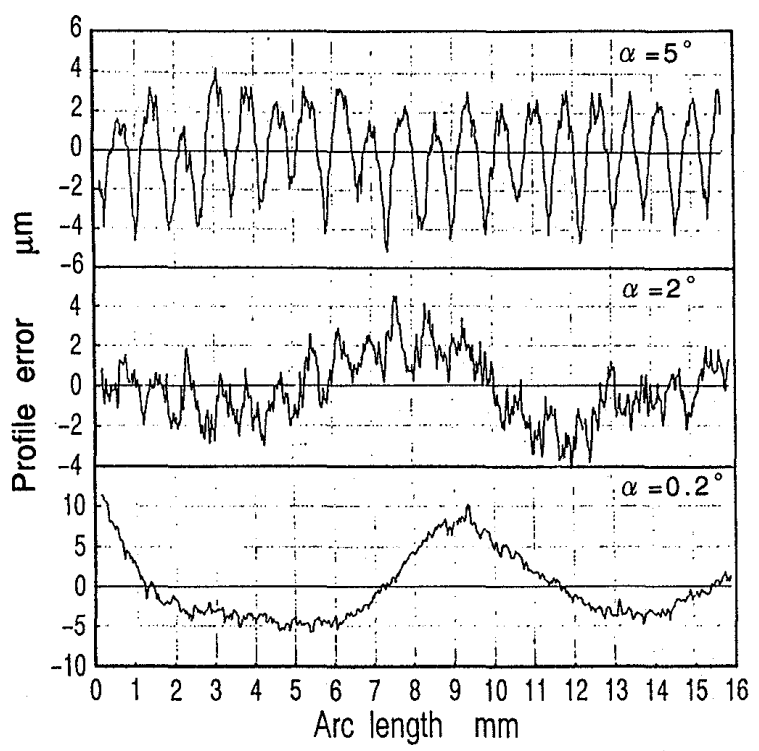

Fig.8 Experimental results at various swing angle $\alpha$

をわずかずつシフトすることによって正多角形の角数 を大きくすることにした．图 9 は, 旋回送り角を $\alpha=5^{\circ}$ にして，反転毎に $\alpha / 4$ だけシフトした時のホイール断 面形状である. 図 7 に比べて高周波誤差が改善され， $\pm 1 \mu \mathrm{m}$ 程度の形状誤差を実現することができた。

\section{4. セラミックスベアリングの総形鏡面研削}

セラミックス材料は軽量で, 耐摩耗性, 耐熱性に優れ, 超高速ベアリングのレース材として適している。ボー ルベアリングのレース面加工には仕上面粗さと共に高 い形状精度が要求され, 現在は主に超仕上によって行 われている。しかし総形鏡面研削加工が可能であれば 加工能率の点で有利である.その上，ゴシックアーチ など非円弧断面のレース面加工も可能になる．本研究 では，円弧断面を有するべアリングインナーレース面 の総形プランジ鏡面研削を試みた.

素材は $\mathrm{Si}_{3} \mathrm{~N}_{4}$ とした. 本研究では円弧ツルーイング法 の応用の可能性を検討することが主目的であったので， レース面の形状精度と粗さに主眼をおいて実験を行っ た。粒度の異なる 3 種類（\#270, \#800, \#5000) のレジ ノイドボンドダイヤモンドホイールを用いて, 粗加工, 中仕上げ，最終仕上げの 3 段階に分け，セラミックスリ ング（外径 $78.5 \mathrm{~mm}$, 内径 $62.5 \mathrm{~mm}$ ）に半径 $8.2 \mathrm{~mm}$ のレ 一ス溝を加工した。 実験条件を表 2 に示す. ツルーイ ングは，それぞれのダイヤモンドホイールよりも粒径 のやや小さいビトリファイド GC 䃌石を用いて行った. 特に極微粒ホイールに対しては，結合度の極めて低い $\mathrm{GC}$ 砥石を使用し残留切込量 $(\Delta-\delta)$ が極力小さくなるよ うにエ夫した.

粗加工および中仕上げは通常の円筒研削盤で行い, 最 終仕上げについては前述の微小切込み装置を備えた超 精密円筒研削盤を使用した。いずれにおいても研削抵 抗の法線分力を監視しながら研削を行った。なお研削 抵抗は，通常の円筒研削盤では心押し軸に貼付した歪

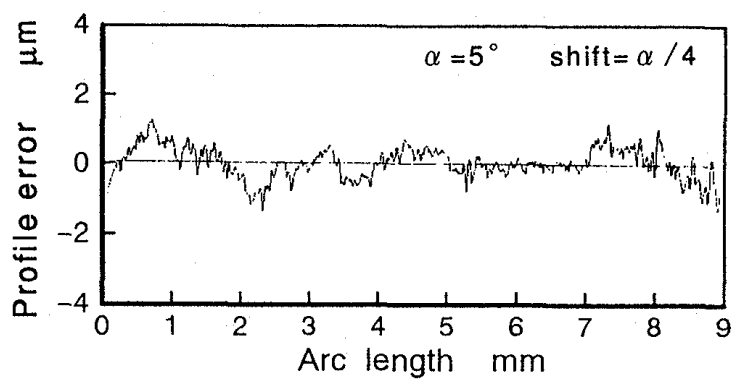

Fig.9 Wheel profile error after shift of swing angle $\alpha$

Table 2 Experimental conditions

\begin{tabular}{|c|c|c|c|}
\hline \multirow[t]{2}{*}{ Machine } & \multicolumn{3}{|c|}{ Cylindrical grinding machine } \\
\hline & \multicolumn{2}{|l|}{ Ordinary type } & Ultraprecision type \\
\hline Workpiece & \multicolumn{2}{|c|}{$\begin{array}{l}\mathrm{Si}_{3} \mathrm{~N}_{4} \\
\text { Noritake COOL SA-02 }\end{array}$} & $\leftarrow$ \\
\hline Grinding process & Rough grinding & Medium grinding & Finish grinding \\
\hline Grinding wheel & SD270P150B & SD800P150B & SD5000P150B \\
\hline Truing conditions & & & \\
\hline Truer & GC280J & $\mathrm{GC1000H}$ & GC6000F \\
\hline Truer speed $V_{t}$ & $106 \mathrm{~m} / \mathrm{min}$ & $\leftarrow$ & $\leftarrow$ \\
\hline Wheel speed V & $330 \mathrm{~m} / \mathrm{min}$ & $\leftarrow$ & $\leftarrow$ \\
\hline Reciprocating rate $V_{R}$ & 17stroke/min & $\leftarrow$ & $\leftarrow$ \\
\hline Depth of cut $D$ & $1.0 \mathrm{~mm} / \mathrm{stroke}$ & $\leftarrow$ & $\leftarrow$ \\
\hline Grinding conditions & & & \\
\hline Wheel speed $V$ & $2310 \mathrm{~m} / \mathrm{min}$ & $\leftarrow$ & $1240 \mathrm{~m} / \mathrm{min}$ \\
\hline Work speed $v$ & $24.7 \mathrm{~m} / \mathrm{min}$ & $\leftarrow$ & $12.3 \mathrm{~m} / \mathrm{min}$ \\
\hline Infeed rate $\quad D_{i}$ & $5.0 \mu \mathrm{m} / \mathrm{min}$ & $2.5 \mu \mathrm{m} / \mathrm{min}$ & $0.1 \mu \mathrm{m} / \mathrm{min}$ \\
\hline
\end{tabular}

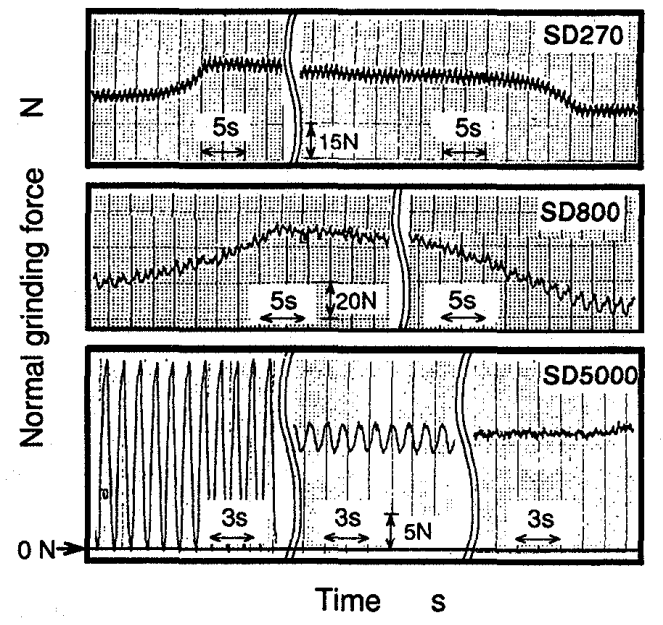

Fig.10 Grinding forces

みゲージにより, 超精密円筒研削盤では砥石軸の静圧 軸受ポケット圧の変動により測定した.SD270P150Bに よる粗加エでは，4個のレースを無垢の状態から削り 出した（総加工量 $1.14 \times 104 \mathrm{~mm}^{3}$ ) が, 研削抵抗は終始 $15 \mathrm{~N}$ 程度で安定した. また SD800P150B による中仕上げ 加工では研削抵抗は約 40N で, やはり安定した研削が 行われた. SD5000P150B による最終仕上げでは, 研削 盤を替えたために取り付け誤差による偏心が生じ，当 初, 図 10 のように研削抵抗が $26 \mathrm{~N}$ まで大きく変動した. しかし研削が進むと振れは次第に除去され，最終的に ほぼ一定の值になった。このように本研究で開発した 


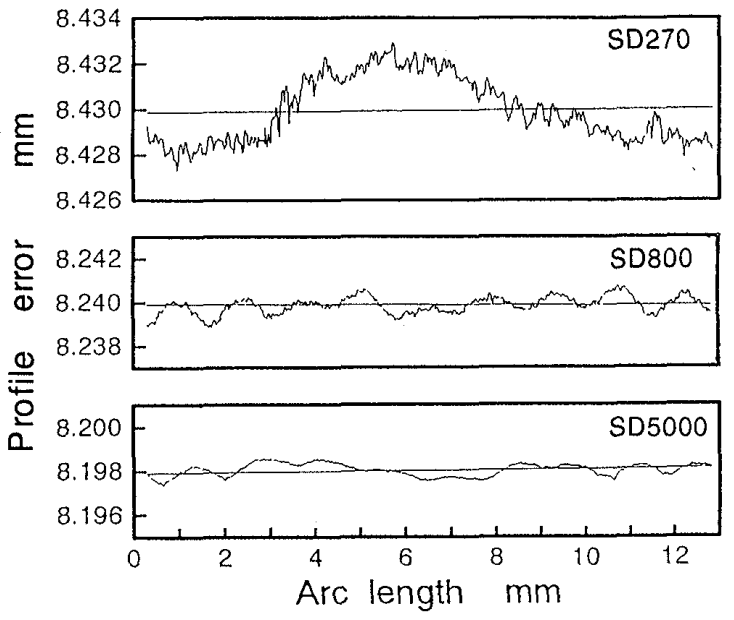

Fig.11 Profile error of ground race surface

アークツルアは，粗粒から極微粒まで幅広く超砥粒ホ イールのツルーイングに有効であることが示された。

図 11 に研削後のレース溝の断面形状, 図 12 に仕上 げ面粗さを示す，最終仕上げでは，目標の形状精度士 $1 \mu \mathrm{m}$ 以下, また仕上げ面粗さ約 $50 \mathrm{~nm} R_{\max }$ の鏡面が得ら れた。図 13 は研削したレース面の写真である。このよ うにプランジ研削にもかかわらず研削条痕の小さい仕 上面が得られるのは, アークッルアではホイールの回 転方向とツルアの回転方向が直交するためである.

\section{5. 結言}

カップッルアをベースにしたアークッルアを改良し て，ツルーイング精度の向上を図った。さらに，この 技術を別途開発した超精密円筒研削盤に応用して, 窒 化珪素セラミックス製ベアリングのインナーレース面 の総形プランジ鏡面研削を行った，得られた結果を要 約すると次のようになる.

(1) アークツルアにおけるツルーイングの創成機構を モデル化し，装置精度に起因するツルーイング誤差 の原因を解析した。この結果に基づき装置の改良を 行った結果, ツルーイングの形状誤差を従来の $1 / 10$ 以下にすることができた。

(2) ツルーイング時の旋回送り角の值によって形状誤 差が影響を受けることを明らかにし，反転の度に送 りの位相をシフトさせる方法によって誤差をさら に减少させ, 最終的に形状誤差 $\pm 1 \mu \mathrm{m}$ の円弧ツルー イングが可能になった。

(3) アークツルアでは, ツルーイングだけでドレッシン グが不要であり，しかも粗粒，極微粒のいずれにお いても，安定で，優れた研削性能が得られた。

(4) 最終仕上げに SD5000P150B のホイールを用い, 窒 化珪素製ボールベアリングのインナーレース面の 総形研削を行い，形状精度 $\pm 1 \mu \mathrm{m}$ ，仕上げ面粗さ約 $50 \mathrm{~nm} R_{\max }$ の鏡面を得た。

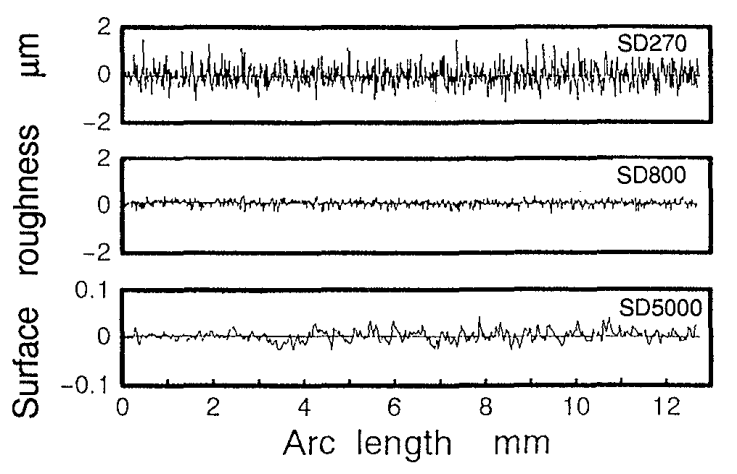

Fig.12 Surface roughness of ground race

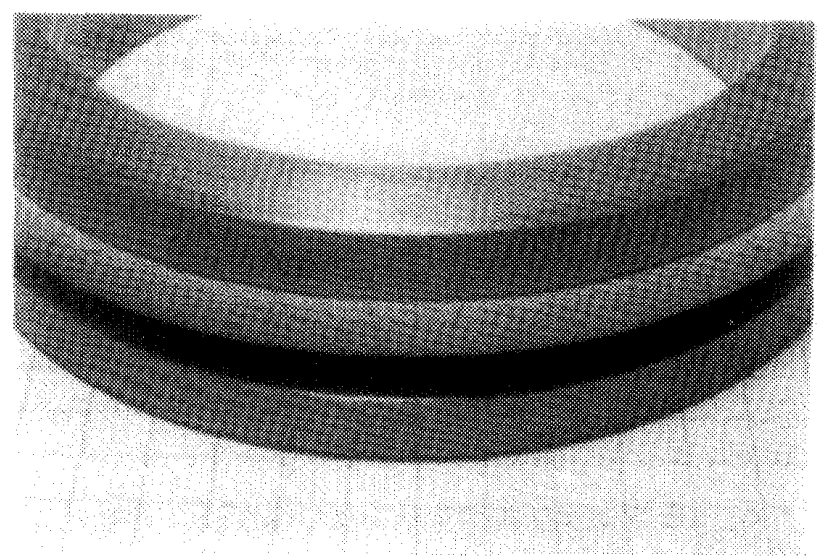

Fig.13 Photograph of mirror finished inner race of $\mathrm{Si}_{3} \mathrm{~N}_{4}$ bearing

\section{謝 辞}

本研究は, 精密工学会産学協同協議会「極微粒ダイヤモンド ホイールを用いた超精密鏡面研削に関する研究協力分科会」の 助成を得て行われた，関倸各位に感謝の意を表する.また実験 に使用した窒化珪素リングは東洋ベアリング株式会社より御 提供いただいたことを記して感謝の意を表する.

\section{文献}

(1) Osaka, K. Unno, A, Tsuboi, Y. Maeda and K. Takeuchi : Development of High-Precision Aspheric Grinding/Truing Machine, Proceedings of the 6th IPES, Braunschweig, (1991) 95.

(2) Subramanian: Make the Best use of CBN Wheels by Proper Truing, Dressing and Conditioning, Cutting Tool Engineering, $39,3(1987)$

(3) Takagi: Sharpness Evaluation and Control of Grinding Face, Yokohama National University Technical Report, 1988.

（4）庄司克雄, 屍川常元, 周立波, 鈴木英俊, 相原秀雄: 総 型研削用超砥粒ホイールのツルーイング法の開発に関す る研究, 精密工学会誌, 59, 3(1993) 117.

（5）庄司克雄，唐建設，周立波，河端則次：マトリックス型 ダイヤモンドホイールの研削性能に及ぼす砥粒と結合剂 の組み合わせの影響, 日本機械学会論文集 (C 編)，61, 586(1995-6) 406.

（6）周立波, 庄司克雄, 或川常元, 海野邦彦, 大下秀男：レ ジンボンド極微粒ダイヤモンドホイールによる円筒鏡面 研削技術の研究，精密工学会誌，61，10(1995) 1438. 